\title{
Electronic forms of political participation in Great Britain - intentions and experiences ${ }^{1}$
}

\begin{abstract}
The present article describes the broad notion of electronic political participation in Great Britain - from grass-roots activities (political movements, protests), to government decisions that lead to the organization and implementation of electronic public services (e.g. e-government, e-voting). Experiences are mostly mentioned as matters related to the turnout, citizen participation in various forms of protests (especially after 2010) as well as Great Britain's accomplishments in terms of e-government. Intentions are first and foremost activities related to the implementation of e-voting in the country. The author of the present article discusses these topics using a case study approach, as well as comparative and descriptive analyses. To do this, the author uses data available in the form of reports, empirical research and press analyses. It has been concluded that the British people are not particularly open to the use of electronic tools in the public sector but there is much organizational and political effort of the elites to implement these solutions. The issue of further work on the development of e-participation in this country (e-voting in particular) remains unsolved.
\end{abstract}

Key words: e-government, e-participation, e-voting, Great Britain

\section{Introduction}

$\mathbf{N}$ owadays various forms of political participation are supported partially or wholly by electronic tools. In representative democracy elections are the most basic form of participation. Participation is the foundation of Joseph A. Schumpeter's procedural democracy, Robert A. Dahl's polyarchy and the model traits of democracy according to Phillipe C. Schmitter and Terry L. Larl (see: Mider, 2008, pp. 138-142). Two different standpoints concerning participation have been formed in the course of analysing this matter. The first one treats voting as the only form of political participation (A. Siegfried, H. Tingsten, H. Gosnell) and casting one's vote is considered as such. The second standpoint treats voting as the central element of political participation (P. F. Lazarsfeld, B. Berelson, H. Gaudet, J. W. van Deth) where its notion is limited to citizens' activities in relation to the election. There also is a third standpoint in which voting is treated as one of many forms of political participation (A. Marsh, S. H. Barnes i M. Kaase). Voting is seen as a unique form of political activity which occurs rarely and cannot be repeated any number of times, unlike the remaining forms of participation. Voting is also negatively preconditioned by strong mechanisms of social control and needs. Furthermore, it is firmly ritualised and does not cost as much for the action-taker as the remaining expressions of participation

${ }^{1}$ Paper prepared under the project: E-voting as an alternative voting procedure in state elections. Experience of selected countries and the perspectives of e-voting implementation in Poland: UMO-2014/15/B/HS5/01358 (NCN, OPUS program). 
(protests, demonstrations, consultations, procedures related to the creation of participatory budgets). Since the end of the 20th century, it can be observed that in many countries less and less citizens want to take part in elections. Sometimes this takes the form of demonstrations, e.g. the "Niepartycypacja" think tank's manifesto: "We do not accept the duress of participation. [...] non-participation does not result solely from idleness, but remains related to cultural and social capital and free time that each of us have. Non-participation is also a type of participation" (Partycypacja, 2012, pp. 97-98). However, societies often employ different attitudes, searching form other forms of participation. Acknowledging that democracy cannot effectively function without the citizens' commitment, other forms of participation are being developed in the democratic process (Cześnik, 2007, p. 19).

Using Great Britain as an example, the author shows the grass-roots activities (social movements, protests) and a plethora of government decisions that lead to the organization and implementation of electronic public services as well as providing information, processes and procedures related to e-government. Great Britain is among the countries that consider implementing e-voting. Some pilot votes have already been performed in this form. Legal foundations for e-voting have also been put in place. However, the matter of implementing e-voting remains open to debate. The aim of the present article is to describe electronic forms of political participation in Great Britain from the point of view of experiences and intentions in this regard. Experiences are mostly mentioned as matters related to the turnout, citizen participation in various forms of protests (especially after 2010) as well as Great Britain's accomplishments in terms of e-government. Whereas intentions are activities that are first and foremost related to the implementation of e-voting in the country. The author of the present article discusses these topics using a case study approach, as well as comparative and descriptive analyses. To do this, the author uses data available in the form of reports, empirical research and press analyses. The article aims to verify the hypothesis that the British people are not particularly open to the use of electronic tools in the public sector but there is much organizational and political effort of the elites to implement these solutions. The issue of further work on the development of e-participation in this country remains unsolved.

\section{Electronic forms of political participation of Brits - experiences}

From numerous definitions and analyses of the notion of political participation, the present article uses its broad understanding as a way of using all forms of participation in public life - from voting and various kinds of protests to citizen activities related to social or political initiatives. Daniel Mider (2008, p. 99) indicated that political participation in its broader sense means general or particular actions which can be instrumental or expressive, voluntary or motivated, legal (legitimised) or illegal (non-legitimised), conventional or unconventional, violent or non-violent, made by a citizen or a political power and are targeted at government bodies or other parties with political power. It seems that modern democracies are characterised by citizens' decreasing activity in the traditional forms of political participation (i.e. in elections) and increasing activity in its new forms (protests and other forms of mobilisation, especially those that use electronic means of communication). Many researchers have the opinion that the use of modern 
technologies has a tremendous impact on the growth of citizen commitment to politics. Jan van Dijk and Kenneth Hacker (2000, p. 1) even indicate that the use of information and communication technologies (ICT) and computer mediated communication (CMC) in all types of media in order to foster political democracy or the citizens' participation in the democratic process leads to digital democracy. On the other hand, Mirosław Lakomy (2013, p. 148), through the use of the terms democracy 2.0 and e-democracy, indicates the following characteristics of democracy: impact on mechanisms of direct democracy, development of voter-politician communication, increase of interest in political processes (e-participation) or the use of ICT in current public administration (e-government). There are opinions that the phenomenon of e-government is directly connected to citizen participation in public debate. This in turn forms the basis for the growth of e-participation, which encompasses all forms of active citizen participation in political process with the use of the Internet and other ICT technologies. ${ }^{2}$ In this section of the article the author concentrates on e-participation. E-government will be analysed in the following section.

The declining turnout in British general elections is a subject of many analyses and distress among numerous researchers and public institutions. ${ }^{3}$ The turnout in the 2001 election, which was reportedly more than $10 \%$ lower than the previous election, raised concerns related to decreased participation in the traditional form of expressing one's political views (see: Graph 1). Even though turnouts are systematically increasing now, we can still observe that citizens are still losing their interest in politics in general and the relationship between voters and political parties is getting increasingly weaker, especially with the two dominant parties in this system. The level of support for individual political parties is indicated by the aggregation index, ${ }^{4}$ the value of which was gradually decreasing in the second half of the 20th century: between 1945 and 1979 it amounted to 15.43, between 1980 and 1990 it was 13.23, whereas between 1991 and 2005 it was 7.93. It can be stated that since the 1980s the support for the two main parties has been decreasing, which triggered a decentralization effect in the system (Antoszewski, Herbut, 2006, pp. 132-133). The genesis of this phenomenon should be traced back to the 1970s, when the first clear lack of the

2 The term e-government related to supplying citizens, entrepreneurs or other government agencies with information and services by government institutions on a national or local scale through the use of the Internet or other digital means. The aim of e-government is to simplify the method of quickly supplying citizens with government information in electronic form, provide citizens them better services, allow access to information without bureaucracy, improve effectiveness and cost-savings as well as increase participation in the political decision-making process. See: Palvia, Sharma, 2007.

${ }^{3}$ In Great Britain the election commission plays the role of a voter activation centre, creating reports from elections and referendums, reviewing and counselling in electoral matters as well as directly promoting citizen education. Due to decreasing turnout during elections, in 2004 a campaign was organized for the promotion of social awareness, called 'Don't do Politics'. Its main goal was to redefine politics so it would be treated as important and personal. This was achieved by showing a direct correlation between politics and common matter that are important to ordinary people. This was conveyed through cartoons and a radio talk show called Chit-Chat in which listeners were not allowed to call and talk on politics-related matters. Social reception of the campaign was very good: $76 \%$ of surveyed citizens recognized at least one element of the campaign and $88 \%$ stated that it explained just how important active participation in elections is (Solon-Lipiński, 2009, pp. 56-58).

${ }^{4}$ An index created by L. Mayer which measures the share of the largest party in comparison with the number of parties holding seats in the parliament. Higher index signifies a more stable and consistent party system (Mayer, 1980). 
division into two major parties (i.e. the necessity to form a coalition government in the 1974) could be observed. This was accompanied by a decrease in their dominance and, in consequence, an increase in the importance of third parties. ${ }^{5}$ At the parliamentary level this was only confirmed in the year 2010 (when due to the hung parliament a coalition between the Conservatives and the Liberal Democrats was formed).

\section{Graph 1. Turnout at General elections in 1964-2017}

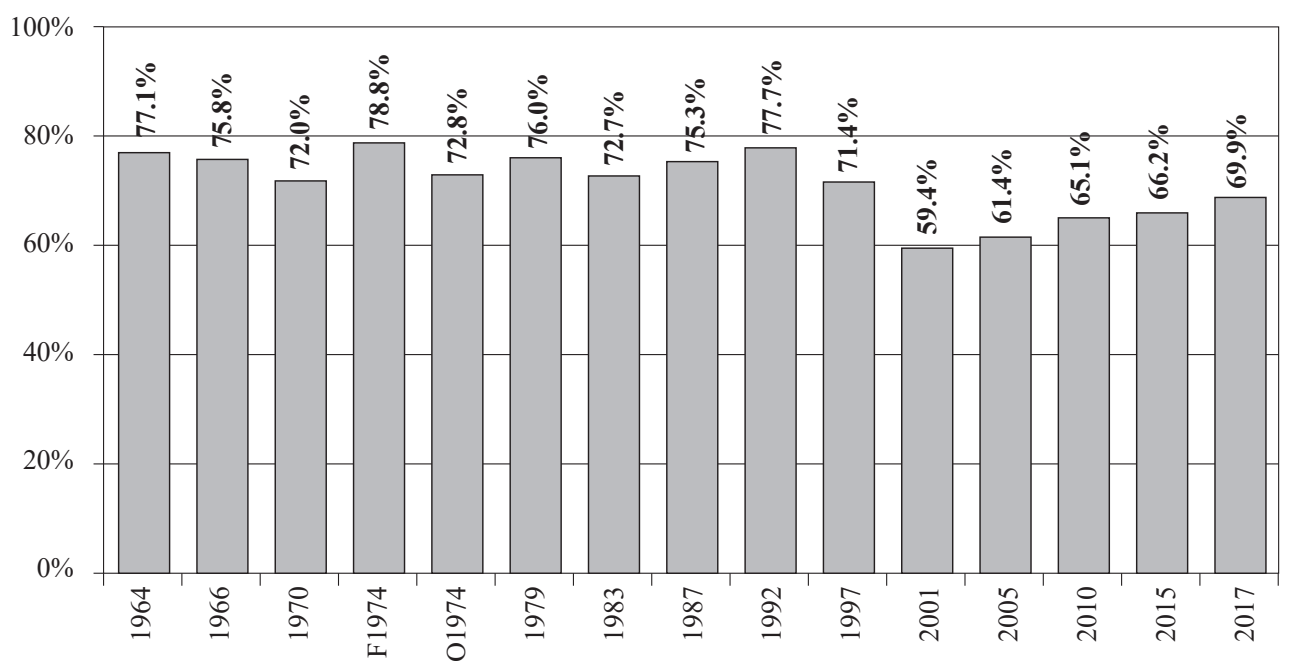

Source: http://www.parliament.uk/briefing-papers/SN02633/turnout-social-indicators-page, 2.06.2018.

${ }^{5}$ The cause and effect of the above is the weakening of the bond between politicians and voters. While until the end of the 1960s, the British political parties could hold ca. $45 \%$ of the so-called iron electorate, currently the percentage of voters who declare their loyalty to a particular party is only at between 10 and 20 per cent and is continuously dwindling. Obviously aside from the above, this is also a consequence of the evolution of political parties. The process of abandoning mass political parties in favour of electoral parties has also caused a decrease in British political party membership. However, the 2010 election indicated a new trend: the importance of non-party members [supporters] in election campaigns. Recent developments in British political parties suggest an increasing role for party supporters - supporters of parties who are not their formal members but make a positive and independent contribution to parties' constituency campaigns. The evolution of party organisations suggests that formal members may be less important than has been previously assumed in the conduct of election campaigns and the extent to which supporter activity complements that of members (Fisher, Fieldhouse, Cutts, 2014, p. 75). Furthermore, new social divisions emerged. These were not class-dependant and created a basis on which the popularity of third parties began to increase. Not only Liberal Democrats gain from this, but also other smaller parties, e.g. UKIP. This is accompanied by decreasing trust of voters towards the ruling parties (39\% in 1974 compared to $16 \%$ in 2009) and views that modern politicians pay no attention to those issues that are important to Great Britain and refuse to cooperate towards common goals. Furthermore, voters also feel that politicians represent their sponsors instead of the electorate (Heath, 2011). This is why even during studies of the voter-party relationship completely new standpoints arise. These reject the ability of social identities (class and religion) to predict individual feelings of partisan attachment, at the same time acknowledging the influence of voters' attitudes towards party leaders (Garzia, 2013, p. 67). More about contemporary British party system in: Kapsa I., 2014, British Party System Change. The Impact of Changing Voters, Devolution and Cabinet Coalition on the Two-Party System, pp. 35-51, "The Copernicus Journal of Political Studies" 1(5), ed. M. Wincławska, Dom Wydawniczy Duet, Toruń. 
Paul Whiteley's (2012, pp. 256) publication presents a pessimistic ascertainment regarding the political participation of Brits: "British citizens are becoming increasingly disengaged from civil society, and that this is having a detrimental impact on the effectiveness of the British government, with grave consequences for the future sustainability of liberal democracy in Britain.” Through an extensive empirical examination, drawing on a vast array of data from multiple sources (including the British Election Study, the European Social Survey, the World Values Survey and the International Social Survey Program), Whiteley examines the essential components of British civil society: the attitudes and values of British citizens towards government, democracy and each other; political participation; engagement with political parties and other social and voluntary organisations and the media. According to his research British citizens are increasingly less likely to engage with political parties; partisanship has declined by $40 \%$ between 1964 and 2005, and the hung Parliament in 2010 was evidence of the major shift in British politics caused by this trend. Contrary to Whiteley, the author thinks that the British society is capable of invigoration. This was proven by the 2010-2017 events: protests criticising the government's politics, then activities related to the independence of Scotland and finally the movements for and against Brexit. A prerequisite for citizens to become active is to overcome a problem that they are facing in the public sphere. Judging its level of importance for individual social, professional and ethnic groups will thus have an impact on whether or not to act. What is also crucial is the ability to identify and publicly promulgate consequences of government decisions related to these groups in order to moblise them.

Forming a coalition in the Parliament and the Cabinet marked the beginning of an ideologically and politically difficult rule of two parties which both politicians and voters alike had to learn. This led to changes in the voter-party relationship which, especially in the traditional model favoured by the Brits, were key factors that formed a certain level of political participation. A few months after the formation of the coalition government, its political program was confronted with the society's expectations. The youngest voters (that arguably have the lowest turnout) have shown the strongest mobilisation to start acting politically. Students protested on the streets of London and many other British cities in response to the government's plans to raise the tuition fees. The commencement of the legislative procedure met with a wave of criticism directed especially at the Lib Dems, who always opposed the idea of raising the fee, but accepted it when being part of the coalition. What is more, it was young adults, the strongest Lib Dems electorate, that the party arguably assailed by accepting the above project. In subsequent demonstrations the high school students were joined by secondary school students, trade union representatives, as well as academics. Outside the capital, students protested in several universities across the country. Other social groups have also opposed the government's money-saving scheme. One hundred and fifty thousand people protested in the streets of London as early as March 2011 against the government's proposals (similar rallies took place in Glasgow and Belfast as well). Moreover, in October 2012 the unemployed, incited by the trade unions, protested in London, Belfast and Glasgow against budget cuts and the liquidation of vacancies. A month later anti-immigrant demonstrations took place in Boston. They were significantly less numerous, but economically important as well. The scale and frequency of these events were unprecedented in Great Britain (see more: Kapsa, 2014). 
The second event that motivated the citizens (albeit Scottish) to act was the referendum regarding the independence of Scotland (2014). This example illustrates that British politics takes place on two levels - regionally and nationally. The Scottish referendum concentrated on ethnic matters, causing the Scots to commit themselves emotionally towards the referendum campaign, also in a virtual environment. At the launch of the Yes Scotland campaign in May 2012, Alex Salmond (BBC, 2012) said that the case for independence would be driven by community activism and "online wizardry." And he was right. The Yes Scotland campaign was ran on Facebook, gaining from about 8,000 to about 23,000 likes by February 2014 and Twitter accounts. This showed the gap between the campaigns increased from approximately 8,000 followers in August 2013 to 13,804 followers in February 2014 in favour of Yes Scotland. Bee and Patchi (2014) propose that shaping active citizenship, motivating civic engagement, and increasing political participation of minority groups have become some of the key political priorities in the UK since at least the end of the 1980s. The 'politics of integration' correspond in fact to a policy response to various social problems (such as discrimination, racism, intolerance) that emerged in various areas, and represent a new political discourse regarding active citizenship. This reflects an overall strategy meant to reframe the basis for civic and political engagement and participation in Britain.

The 2016 Brexit referendum was particularly important to the whole British society. As analysed by Frances Smith (www.referendumanalysis.eu), the surprise outcome of the EU referendum has exposed the extent of divisions within the UK. These differences are geographical, also vary by age, gender and level of education, with the paradigmatic Remain voter a young female Scottish graduate and the archetypal Brexiteer a 50 plus Englishman with less formal education and limited means. The disparity between these identities is clear. Yet more nebulous than ever is the cultural construct of "Britishness" which was mobilised in service of both the Remain and Leave campaigns. In the "How leave won Twitter" article (Hänska, Bauchowitz, 2017, p. 29) it is stated that Twitter users who supported leaving the EU were more numerous, and Eurosceptic users in general were more active (they tweeted more frequently) than the remaining users. Arguably, the social media are dominated by young people, who are, interestingly enough, regarded as those who withdraw from the formal political process (Henn, Foard, 2014, pp. 360-380). Young people in Britain are often characterised as disconnected from the formal political process and from democratic institutions. In turn, politicians are less and less interested in this group of voters. However, today's generation of young people is interested in political affairs - they are keen to play a more active role in the political process.

\section{British e-government}

Literature regarding the provision of public services electronically in Great Britain indicated that some authors criticise this matter rather strongly. In the beginning of the 21 st century people referred sceptically towards the changes of introducing an entire e-government in Great Britain (British Slow, 2003; Lee, Tan, Trimi, 2005), pointing especially at the role of local administration in the process of implementing this type of communication (Turner, Higgs, 2003). Soon it turned out that the government's strategy, 
preparations of legal bases and equipping institutions with the right technology and improving Internet access resulted in increasingly positive evaluations of e-government in Britain. The decade 1998-2008 has seen many policy initiatives in this area and substantial dedication of resources to electronic government. E-government may be defined as the use by government of the internet and related information technologies internally and to interact with citizens, firms, voluntary organisations and other governments (Margetts, 2008, p. 155). The early 2000s were the 'boom' period for e-government in the UK and many other countries. At this time the governments of almost all developed nations embarked on some kind of e-government initiative and many introduced targets for the percentage of governmental transactions that were to take place online. A strategy has been devised to improve public services for citizens and businesses and increase the effectiveness of using the government's information resources (Chadwick, May, 2003, p. 289). Moreover, the number of Internet users is still rising. Between 1998 and 2008, Internet penetration in the UK rose from around 10 per cent to over two-thirds of the population. In Quarter 1 (Jan to Mar) 2017, $89 \%$ of adults in the UK had recently used the Internet (in the last 3 months), up from $88 \%$ in 2016; while $9 \%$ had never used the Internet, down from $10 \%$ in 2016 (ons.gov.uk).

A crucial indicator of e-government's level of development is the UN Department of Economic and Social Affairs Report, according to which in 2016 Great Britain was a world leader in this regard and is still one of the top countries (4th place in 2018). E-governmnent is assessed on the basis of the EGDI indicator which presents the state of E-Government Development of the United Nations Member States (UN e-gov Survey, 2016). Along with an assessment of the website development patterns in a country, the E-Government Development index incorporates such access characteristics as the infrastructure and educational levels, to reflect how a country is using information technologies to promote access and inclusion of its people. The EGDI is a composite measure of three important dimensions of e-government, namely: provision of online services, telecommunication connectivity and human capacity. The authors of the report assess that in the last decade the British government worked continuously to establish the needed infrastructure; and secure government gateways, interoperability standards, authentication and broadband availability, while also deregulating the telecommunications sector. With the basic infrastructure in place, attention was turned to ensuring faster and more innovative adoption of new technologies for online service delivery. The e-government service progression went from simply publishing information to offering basic interactions, (e.g., e-forms), to full transactional capability (e.g., filing and processing tax returns, welfare benefits, passports, etc.) and to a more complete transformation and reform of public sector online operations and public service delivery. The governance of online public service delivery was changed with the introduction of Chief Information Officers (CIOs) Council and between the e-Government Unit of the Cabinet Office and the Office of Government Commerce. This team was set to transform online service delivery and make it citizens centred, self-service, accessible and enabling. This marked a Whole-ofGovernment approach in online service delivery, where services are available in a more integrated fashion from various departments; local and central governments. Digital authentications, as well as secure access to the full spectrum of services are being ensured along with efforts to promote digital inclusion. 
The British e-government uses numerous tools - for example the gov.uk website (it is the website of the UK government). It provides the people and businesses in England and Wales with easy and effective digital access to all public services and related information. The site it maintained by the Government Digital Service. Since the launch of the gov.uk platform 312 agencies and Arm's Length Bodies websites were transitioned to GOV.UK and over 1,800 separate sites have been closed) through networks (Government Secure Intranet, Public Services Network, etc.), eIdentification, eProcurement, and many services for citizens. These are, among others: income taxes: declaration, notification of assessment; job search services by labour offices; social security benefits; personal documents: passport and driver's licence; car registration (new, used, imported cars); application for building permission; declaration to the police (e.g. in case of theft); public libraries (availability of catalogues, search tools); certificates (birth and marriage): request and delivery; enrolment in higher education/University; announcement of moving (change of address); health related services (interactive advice on the availability of services in different hospitals; appointments for hospitals).

In spite of the fact that the infrastructure has been perfectly organised, its use by the citizens still the remains a problem. Internet access is not a barrier in itself (as described earlier). However, there are some disproportions in terms of age categories. While almost all adults aged 16 to 24 years (98\%) had accessed the internet "on the go," only $39 \%$ of those aged 65 years and over had done so (ons.gov.uk). In 2017, still the most popular Internet activity was sending or receiving emails ( $82 \%$ of adults), up 3 percentage points from $79 \%$ in 2016. The most common form of using public services was finding information about goods and services. It was the second most popular form among $71 \%$ of adults, up from $58 \%$ in 2007. Such an increase is not, however, present in terms of using the Internet for interacting with public authorities. Percentage of individuals using the internet for interacting with public authorities in UK is from 48\% in 2010 to $49 \%$ in 2017 (Eurostat). It is clear that this is a great challenge for the British government.

\section{Experiences and plans related to e-voting}

Great Britain's success in implementing e-government opens up a discussion about the full revolution of the public sphere, in particular regarding the development of electronic voting. A programme of research and implementation is already underway, ranging from national projects aimed at establishing a standard basis (for example, a standardized electoral register) to a consultation programme and implementation strategy (Pratchett, Wingfield, p. 172). The electoral law has been altered to allow local governments to experiment with different forms of e-voting. Government-funded pilots that tested different types of e-voting (among other experiments) first took place in the local government elections of 2000 and were greatly extended in the local elections of May 2002 to include remote electronic voting. In England voting pilots have taken place in May 2000, May 2002, May 2003, June 2004, and May 2006. In 2000 and 2004, the London Mayoral and in 2004 European Parliamentary elections Assembly elections were counted using an optical scan voting system. Both elections required some editing of the ballot design to facilitate electronic tabulation, though they differed only slightly from 
the previous "mark with an X" style ballots. Since May 2002, a variety of electronic voting procedures have been piloted across a number of local authorities in English local council elections (Wilks-Heeg, 2009, p. 105). In their more limited form, these pilots have involved making computer terminals available within polling stations. However, there have also been numerous pilots of "multi-channel" electronic voting, enabling voters to cast ballots remotely via the Internet, telephone or SMS, often with a facility for advance voting before polling day. The most systematic piloting of electronic voting in the United Kingdom has taken place in Swindon, where pilots of remote voting via the Internet, telephones and digital television, as well as the use of mobile electronic voting kiosks and laptops within polling stations, were run at local elections in 2002, 2003 and 2007. Even though reviews of these elections were positive, evaluation reports of the Electoral Commission (electroalcommission.org.uk) indicated utmost disappointment: the e-voting pilots had little or no impact on turnout.

There were e-voting trials in Scotland as well. An optical scan voting system was used to electronically count paper ballots in the Scottish Parliament general election and Scottish council elections in 2007. A report commissioned by the UK Electoral Commission found significant errors in ballot design produced more than 150,000 spoilt votes. The $\mathrm{BBC}$ reported that 86,000 constituency ballots and 56,000 list ballots were rejected, with suggestions that it was caused by voters being asked to vote for both sections of the election on the same ballot paper, rather than on separate ballots as had been the case in the previous elections. The electronic counting was used again in the 2012 and 2017 council elections without any problems.

Lawrence Pratchett and Melwin Wingfield (2004, pp. 172-189) have the opinion that while the pilot approach offers some considerable experience in organizing and managing e-enabled elections, it does little to address the key implementation issues that need to be overcome before e-voting can be a mainstream feature of the electoral system. They claim that despite expensive pilots that tested a range of technical options, the lessons from current pilots are extremely limited and do not address the substantive policy problems facing implementation. These two researchers are not isolated in their sceptic opinion. In light of the politicians' announcements regarding the implementation if e-voting in Great Britain (John Bercow, the Commons Speaker, said in 2015 that he wants electronic voting for the 2020 general election. He argues that the change is necessary to ensure that the younger smartphone generation of voters remain engaged with the democratic process) many publicists and experts express their concerns in relation to this procedure. The most serious concerns relate to security and possible electoral fraud. The chief fear of many is that a switch to electronic voting would make electoral fraud easier, not harder. In the worstcase scenario, rather than forging ballots individually, a wannabe dictator could simply flip a switch and win the election with no trail in sight. Jim Killock, the executive director of the Open Rights Group, says that voting has to be secret, secure and accountable (Hern, 2015). According to some, the challenge, or rather an impossible obstacle to overcome, lies in the creation of an IT system that needs to do the following: verify the identity of around 50 million users within a 15 hour period; anonymously register their votes, so that no connection can ever be made between verified identities and votes cast; store the data behind those votes in a fashion that allows independent verification and checking after election, and in a form that absolutely cannot be altered or manipulated after the fact; and do all this 
without any scope whatever for hacking, penetration or even just crashing during the voting period. They claim that failing even slightly on any one of those things will undermine one of the foundations of our system of governance, acceptance of the democratic legitimacy of our government (Kirkup, 2015).

Many of these concerns may be eliminated. Stephen Coleman (2005, p. 95) claims that the risk of such symbolism for the political elite - and a democratic opportunity for citizens - is that online voting will stimulate a public appetite for a more interactive system of representation before and after elections. The movement towards more direct representation presents a formidable challenge to remote representatives, but, as I have argued elsewhere, may be one of the most hopeful options for the future of democracy. An argument for implementing e-voting is also the chance of eliminating vote-counting errors and lowering costs. Electronic voting machines are used in some of the world's biggest democracies, including Brazil, India, and the Philippines, to get around some of these hurdles. The concept of electronic voting has garnered widespread political support, seen as both a cost-saving measure and a possible way of boosting turnout in an era of declining voter representation (from the Labour Party's manifesto): "Labour is committed to looking at radical ways of encouraging more people to vote, by making the process easier and more in tune with the way people live their lives ... Labour will pilot secure systems for electronic voting, including online voting."

The Local Government Association report regarding the implementation of electronic voting in the UK (2002) stated that in the beginning of the 21st century lack of Internet access was a serious limitation to implementing e-voting. This issue is not only a problem in terms of access, it is also a problem in terms of voter capacity to use the voting technology. Experience and willingness to use it are intrinsically linked. When a significant decrease in turnout occurred, the government searched for solutions to avert this trend and e-voting was one of the proposals. Electronic voting in supervised polling places appears to be a sensible compromise that avoids the numerous pitfalls of homebased forms of electronic voting while at the same time meeting public demands for greater convenience and flexibility in voting (Birch, Watt, 2004, p.71). Norbert Kersting and Harald Baldersheim (2004) prove that Internet voting removes some of the physical and time-related barriers that disable many from voting; it is especially beneficial to someone who cannot vote because they are elderly, disabled, must work twelve hours a day or has child care problems. Second, Internet voting might improve the legitimacy of those votes that are taken. By increasing participation from thirty or forty percent to perhaps an optimistic fifty or sixty percent, those votes that are taken may resonate even more deeply with any of the normative reasons. So far, the matter of e-voting is still a subject of debate and not political decisions.

\section{Conclusions}

The presented examples of electronic forms of political participation in Great Britain (voting, e-mobilisation, protests and e-government) indicate that this country successfully managed to organise and implement electronic public services. However, their usage and subsequent works on their further development (i.a. in the form of e-voting) raise some 
doubts. These are mainly related to a large stratification of the British society in terms of political interest, which is confirmed by a hypothesis regarding the mixed openness (largely due to age) of the Brits towards the use of electronic tools for public services with much organizational and political effort of the elites to implement these solutions. The issue of further work on the development of e-participation in this country remains unresolved, not so much in terms of new solutions, but rather to increase the number of citizens using the existing e-government system. These types of issues are considered by decision-makers and researchers advise that a decentralised rather than a top-down approach is particularly suitable, which can encourage innovation in the public sector and involve citizens in the implementation of policies. As a method of evaluating interventions, randomised controlled trials have a unique role to play in improving the design of policies, particularly if carried out responsively and adaptively. A culture of experimentation would value curiosity, feedback and the continual testing of interventions (John, 2013, p. 238).

\section{Bibliography}

Antoszewski A., Herbut R. (2006), Systemy polityczne współczesnej Europy, Wydawnictwo Naukowe PWN, Warszawa.

BBC (2012), http://www.referendumanalysis.eu/eu-referendum-analysis-2016/section-5-campaignand-political-communication/britishness-and-brexit/.

Bee C., Pachi D. (2014), Active Citizenship in the UK: Assessing Institutional Political Strategies and Mechanisms of Civic Engagement, "Journal of Civil Society", Apr, vol. 10, Issue 1.

Birch S., Watt B. (2004), Remonte Electronic Voting: Free, Fair and Secret?, The Political Quaterly Publishing.

British Slow to Use e-Government Services (2003), "The Information Mamagment Journal”, March/ April.

Chadwick A., May Ch. (2003), Interaction between States and Citizens in the Age of Internet: "e-Government" in the United States, Britain, and the European Union, "Governance: An International Journal of Policy, Administration and Institutions", vol. 16, no. 2.

Coleman S. (2005), Just how risky is online voting?, "Information Polity" 10.

Cześnik M. (2007), Partycypacja wyborcza w Polsce. Perspektywa porównawcza, Wydawnictwo Naukowe Scholar, Warszawa.

Fisher J., Fieldhouse E., Cutts D. (2014), Members Are Not the Only Fruit: Volunteer Activity in British Political Parties at the 2010 General Election, "British Journal of Politics \& International Relations), vol. 16, issue 1.

Garzia D. (2013), Changing Parties, Changing Partisans: The Personalization of Partisan Attachments in Western Europe, "Political Psychology", vol. 34, issue 1.

Hacker K. L., van Dijk J. (2000), Digital Democracy: Issues of Theory and Practice, Sage Publications, London.

Hänska M., Bauchowitz S. (2017), Tweeting for Brexit: How social media shaped the Referendum campaign, in: Brexit, Trump and the Media, eds. J. Mair, T. Clark, R. Snoddy, R. Tait, Abramis, Suffolk.

Heath O. (2011), The great divide: voters, parties, MPs and expenses, in: Britain at the polls 2010, eds. N. Allen, J. Bartle, SAGE Publications, London.

Henn M., Foard N. (2014), Social differentiation in young people's political participation: the impact of social and educational factors on youth political engagement in Britain, "Journal of Youth Studies", April, vol. 17, issue 3. 
Hern A. (2015), Should Britain introduce electronic voting?, "The Guardian”, https://www.theguardian.com/technology/2015/feb/26/should-britain-introduce-electronic-voting.

John P. (2013), Experimentation, Behaviour Change and Public Policy, "Political Quarterly" AprilJune, vol. 84, issue 2.

Kapsa I. (2014), „Demokracja na ulicach Londynu” - analiza protestów politycznych w Wielkiej Brytanii po wyborach parlamentarnych 2010 roku, in: Dyskurs publiczny w praktykach społecznej kontestacji, red. J. Golinowski, A. Kaszkur, Wydawnictwo UKW, Bydgoszcz.

Kersting N., Baldersheim H. (2004), Electronic voting and democracy: a comparative analysis, Palgrave Macmillan, London.

Kirkup J. (2015), Why we don't have electronic voting, The Telegraph, https://www.telegraph.co.uk/ news/general-election-2015/11369276/Why-we-dont-have-electronic-voting.html.

Lakomy M. (2013), Demokracja 2.0. Interakcja polityczna w nowych mediach, Akademia Ignatianum, Cracow.

Lee S. M., Tan X., Trimi S. (2005), Current Practices of Leading e-Government Countries, "Communication of the ACM", October, vol. 48, no. 10.

Margetts H. (2008), Information Exchange between Government and Citizens, "The Political Quarterly Publishing".

Mayer L. (1980), A Note on Aggregation of Party systems, in: Western European Party Systems, ed. P. H. Merkl, Free Press, New York.

Mider D. (2008), Partycypacja polityczna w Internecie. Studium politologiczne, Wydawnictwo Elipsa, Warszawa.

Palvia S. C. J., Sharma S. S. (2007), E-Government and E-Governance: Definitions/Domain Framework and Status around the World, http://www.iceg.net/2007/books/1/1_369.pdf, 7.06.2018.

Partycypacja. Przewodnik Krytyki Politycznej (2012), Krytyka Polityczna, Warsaw.

Pratchett L., Wingfield M. (2004), Electronic Voting in the United Kingdom: Lessons and Limitations from the UK Experience, in: Electronic Voting and Democracy A Comparative Analysis, eds. N. Kersting, H. Baldersheim, Palgrave Macmillan, London.

Solon-Lipiński M. (2009), Aktywizowanie wyborców. Inicjatywy z różnych krajów świata, Instytut Spraw Publicznych, Warszawa.

Szczegóła L. (2013), Bierność obywateli. Apatia polityczna w teorii demokratycznej partycypacji, Wydawnictwo Elipsa, Warszawa.

Turner P., Higgs G. (2003), The use and management of geographic information in local e-government in the UK, "Information Polity" 8.

UN e-gov Survey (2016), New York, http://workspace.unpan.org/sites/Internet/Documents/UNPAN97453.pdf.

Whiteley P. (2012), Is it Time to Update the Definition of Political Participation? Political Participation in Britain: The Decline and Revival of Civic Culture, Palgrave Macmillan, Basingstoke.

Wilks-Hegg S. (2009), Treating Voters as an Afterthought? The Legacies of a Decade of Electoral Modernisation in the United Kingdom, "The Political Quarterly", January-March, vol. 80, no. 1.

\section{Elektroniczne formy partycypacji politycznej w Wielkiej Brytanii - doświadczenia i zamierzenia}

\section{Streszczenie}

Artykuł prezentuje szeroko rozumiane elektroniczne uczestnictwo polityczne na przykładzie Wielkiej Brytanii - od działań oddolnych (ruchy społeczne, protesty), po decyzje rządowe, w wyniku 
których w tym kraju zorganizowano, wdrożono i realizuje się świadczenie usług publicznych drogą elektroniczną (e-admnistracja, głosowanie elektroniczne). Wśród doświadczeń wymienia się przede wszystkim kwestie związane z frekwencją wyborczą, partycypacją obywatelską w różnych formach protestu (zwłaszcza po 2010 roku), a także osiągnięcia Wielkiej Brytanii w zakresie e-administracji. Jeśli chodzi o zamierzenia, to chodzi przede wszystkim o działania na rzecz wprowadzenia głosowania elektronicznego w tym kraju. Autorka posługuje się metodą analizy przypadku, analizy porównawczej, a także opisową. Sięga po dane dostępne w formie raportów i badań empirycznych, a także posługuje się analizą prasy. Wśród wniosków zwraca się uwagę na ograniczoną otwartość Brytyjczyków na zastosowanie narzędzi elektronicznych w sektorze publicznym, przy jednoczesnym dużym wysiłku organizacyjnym i politycznym elit politycznych $w$ ich wdrażaniu. Pytaniem otwartym zostaje kwestia dalszych prac nad rozwojem elektronicznej partycypacji w tym kraju (zwłaszcza głosowania elektronicznego).

Słowa kluczowe: e-administracja, e-partycypacja, głosowanie elektroniczne, Wielka Brytania 
